\title{
The Evolution of the Party's Educational Policy since the Founding of the People's Republic of China and Its Enlightenment to College Ideological and Political Education
}

\author{
Zhou Lei \\ China Jiliang University \\ Hangzhou, China
}

\begin{abstract}
The Party's educational policy has always been the guiding principle for guiding and implementing education in our country. Since the founding of New China, our leaders have made certain changes to educational policies of different periods according to actual development of China at various stages. The article starts with the education policy, mainly including its concepts and characteristics, and then analyzes the evolution of the party's educational policy since the founding of the People's Republic of China in-depth, and finally provides a reference for the educational goals, educational links and educational purposes of ideological and political education in colleges and universities.
\end{abstract}

Keywords-party's educational policy; evolution process; college ideological and political education; inspiration

\section{INTRODUCTION}

There is such a famous saying about education in China education is good for the country, and education is strong for the country. The role of education is not only to give people access to knowledge, in this society, it is the cradle of cultivating the future socialist successor in China, therefore, education plays a crucial strategic role in the development of China's future socialist cause. The education policy is essentially serving the development of the country. It is a general direction for a country-related political party or leader to develop education for a specific development period in the country.it is the direct force that determines the direction and speed of future education work. In the past 70 years since the founding of the People's Republic of China, the evolution of China's educational policy has reflected the development of China's socialist cause, it provides some enlightenment for colleges and universities to better implement the socialist modern state education policy and train new people in the socialist era.

\section{THE MEANING AND CHARACTERISTICS OF THE EDUCATION POLICY}

\section{A. The meaning of the education policy}

The educational policy is a term with Chinese characteristics, and many related educators have conducted detailed research on it. Gu Mingyuan pointed out in his " Educational dictionary" that the education policy is based on the state of education development in different countries. A document that guides the development of education in combination with social and individual needs, the contents mainly include the explanation of the purpose, nature and development path and direction of education. In Xiao Zongliu's view, the educational policy is not only to serve the education work, but also to serve the development of the country. It depends on the actual development of the country in political, economic and social aspects.

Summarizing and summarizing the definitions of relevant scholars, coupled with the clear definition of the educational policy of relevant institutions in China, can lead to a more comprehensive conclusion: the educational policy is first and foremost a guidance document on the direction of development of educational work in the future; secondly, it is proposed by a country's ruling party or leader to integrate the development of the country during that period. As a basic principle guiding the development of education, the education policy is mainly reflected in the following three aspects: the first is to decide what kind of talents to train in the future; the second is to decide what methods and ways should be adopted for talent training; and the third is to cultivate these talents for what. China's educational policy is the product of the combination of the basic theory of Marxist education and the reality of Chinese education. It is a theoretical combination of exploring the path of socialist education with Chinese characteristics and affects the basic purpose and fundamental direction of educational development in the future. 


\section{B. Basic characteristics of the education policy}

Educational policies are easily confused with many concepts of education, such as educational purposes, educational requirements, educational policies, educational laws, and educational regulations. The educational policy is a broad concept compared with these concepts. It has great development significance for guiding the overall situation and has the following four basic characteristics.

\section{1) Theoretical authority}

The education policy, as the general guide of education work, stipulates the general direction of education work. Other local education policies, education regulations, and educational requirements must not conflict with the party's educational policy. After the education policy was proposed, a series of documents on education were also developed to better help the implementation of the education policy. In turn, the education policy actually has a certain guiding effect on these policies and regulations on education, and is authoritative; education laws and regulations must also follow the party's specific education policy, and all education laws and departmental regulations must follow relevant education laws.

\section{2) Historical stage}

Education serves the ruling class in any country and society. Education is also the basic way for the ruling class to better maintain political rule and achieve social stability. The educational policy of the socialist countries needs to train builders and successors for the socialist cause. Therefore, for our country, the education policy formulated by the Communist Party should always follow a principle that all provisions are for the benefit of the people, and education is no exception. We must fully consider the wishes of the people. According to China's current actual development, the problems in the development of education are mainly the problems between the people's growing demand for quality education and the imbalance of the current state of education development in China, according to the clear guidance in China's current education policy, we must accelerate the cultivation of quality talents, and thus promote the improvement of social harmony and people's happiness.

\section{3) Relative stability}

Education is a long-term practice of cultivating people, and talent cultivation also has objective regularity. Therefore, the education policy must also obey the development law of the times and the types of social demand for talents, and cultivate new talents that meet the requirements of the times. Looking closely at the changes in the education policy in these decades, we can clearly see the core idea of the party in formulating the educational policy, that is, the leading body of education work is always the Communist Party, and the fundamental nature and fundamental value orientation of education work. They are all carried out around the main body of the people and have a very distinct people's character. The basic ideology and core content of the party's educational policy must be in the same line. The nature of socialism has always been the fundamental background and environment of education, and the goal of education for talent training cannot be changed. We must always adhere to the cultivation of the goal of comprehensive development of talents. The "unchanged" nature of this core content maintains the relative stability of the educational policy, and at the same time lays the foundation for the inevitability of the development of China's educational work.

\section{4) Distinctive times}

Since the educational policy has realistic guiding significance for the development of education, it will present different characteristics in different stages of historical development, and at the same time put forward higher requirements for talent cultivation. When these new requirements and new changes accumulate to a certain extent in the historical context of the new era, it is necessary to propose corresponding education guidelines. Therefore, different stages of education are needed at different stages of development in the country to guide the direction of education at this stage, and even at the same stage of development, the differences in educational approaches may differ in some respects.

\section{THE EVOLUTION OF THE PARTY'S EDUCATIONAL POLICY SINCE THE FOUNDING OF NEW CHINA}

\section{A. Education policy in the early days of the founding}

In 1949, at the beginning of the founding of the People's Republic of China, the government education department held its first meeting in Beijing. At this meeting, relevant leaders discussed and clarified the educational policy of that historical period: due to the problems left over from history, we must speed up the improvement of the cultural level of our people. At the same time, we must let people get rid of the old ideas of the old feudal society through education, and replace the traditional feudal ideas with the idea that new China serves people in the new era.

In 1957, Comrade Mao Zedong, then the leader of the country, adjusted the main purpose of the education policy according to the development and changes in China's economy and politics at that time. He pointed out: "The purpose of education in this period is not only to upgrade the people's cultural level and to get rid of old ideas. Now the purpose of education is to make every educated person develop and progress in all aspects of morality, intelligence, and so on. In the end, it will become a talented person in all aspects."

\section{B. The party's education policy was seriously distorted during the Cultural Revolution}

From May 1966 to October 1976, an "unprecedented" "cultural revolution" took place in China. During this decade, China's education industry has been hit hard, not only without progress, but even with a retrogressive trend. The "Cultural Revolution" has caused serious harm to the cause of socialist education. Although the education policy has also changed during this special period, under the misunderstanding and falsification of Lin Biao and the "Gang of Four" group, the party's original education policy was completely deviated, resulting in the great destruction of the socialist education cause.

On May 7, 1966, based on the wrong estimation of the form, Mao Zedong put forward that "for the study of students, we can no longer learn the same text as before, and we must learn from the aspects." Students should study less time and 
eliminate the leadership of the bourgeoisie in education. "This directive contradicts Mao Zedong's educational policy in 1957 from content to form, and provides theoretical and guiding ideology for Lin Biao's and the "Gang of Four" so-called educational revolution. Mao Zedong's instructions on the transformation of the educational policy did not play a minor role. Instead, Lin Biao and his "Gang of Four" implemented the two estimates of education work at the time. The most complete, in fact, during these seventeen years. The leadership of the bourgeoisie in education is much higher than that of the proletariat. Therefore, the students trained in this period are all bourgeois students. They also have the common belief that the bourgeoisie is completely correct. The two estimates made by Lin Biao and the "Gang of Four" on education work have greatly contributed to the leadership of education in China for a long time, which has brought a devastating blow to the development of education in China. Deviating from the educational policy put forward by the party, the level of education in the country has been reversed for a long time, and the party's leadership in education has once deviated from the right track.

\section{The continuous improvement of the party's education policy since the reform and opening up}

After the Third Plenary Session of the 11th Central Committee, the Communist Party re-established a new education policy. At the same time, we have established the most basic ideological line and action guide, which is to seek truth from facts and adhere to practice. This meeting also marks a new era in which China's reform and opening up has entered a period of rapid development. In this new era of reform and opening up, we have established a new fundamental task, that is, we must fully accelerate the building of socialist modernization and strive for the early establishment of a socialist modernization power. This is also the development direction of the education policy in this period.

At the special education work conference in 1978, Deng Xiaoping hosted the meeting and delivered a speech. In this speech, Comrade Deng Xiaoping clearly stated that he must fully implement the instructions put forward by Comrade Mao Zedong to achieve comprehensive development and common promotion in education, let students achieve common development and progress in all aspects of morality, intelligence, and beauty. In September of 1983, based on the research and prospects of China's educational status, Comrade Deng Xiaoping once again put forward his views on education. He believes that our education is not limited to the present and the country. Our education is to make plans for future development. It should face the world and face the future. Comrade Deng Xiaoping's directive immediately became China's development concept of education in the new era of reform and opening up. In April 1986, the relevant leaders of the party discussed and adopted the compulsory education law program, which clearly stated that we must implement compulsory education throughout the country so that every child can enjoy free education from the state, improve the overall cultural level of our country. This legally ensures the implementation of the education policy in the compulsory education stage.

\section{THE ENLIGHTENMENT OF THE PARTY'S EDUCATION IN THE NEW ERA ON COLLEGE IDEOLOGICAL AND POLITICAL EDUCATION}

A. Coordinating the all-round development of people with strengthening moral education and cultivating talents are the primary goals of ideological and political education in colleges and universities

It has always been a major problem in China's education about what kind of talents should be cultivated in education and how to cultivate such talents. After General Secretary Xi Jinping came to power, he put forward a new view on this core issue of education. Establishing strength moral education and cultivate people as the most basic task of college education in China is also the most fundamental task. As the main front for the cultivation and export of talents in China, colleges and universities have unshirkable responsibilities and obligations for the cultivation of the broad masses of young students. With the development of the times and the new educational policy adapted to social development, colleges and universities should take the initiative to adapt to the new education policy and actively adjust the education and teaching training model., adhere to the educational guidelines of strength moral education and cultivate people and work hard to cultivate socialist builders and successors who are fully developed in morality, intelligence, and work.

\section{B. Putting the education policy of the New Era Party into the} whole process of personnel training is an important part of the ideological and political education work in colleges and universities

The educational policy established in the new era needs to be implemented in all aspects, including the training of students, the training of students, and the training of students, both in the planning and specific training process of students. The concept of all-round development educates students, thus cultivating new talents for socialist construction in the new era of China. The first of these is to educate students. Mr. Tao Xingzhi once said that if a person has no morality, then no matter whether his or her knowledge or ability is large, he will not actively contribute to society and the people. It only creates harm. Therefore, it is necessary to fully highlight moral education and train students to become people with great love and great feelings.

\section{Cultivating new people in the socialist era with all-round} development of morality, intelligence, art and work is the fundamental purpose of ideological and political education in colleges and universities

The report of the 19th National Congress of the Communist Party of China pointed out that "we must fully implement the Party's educational policy, implement the fundamental tasks of strength moral education and cultivate people, develop quality education, promote education equity, and cultivate socialist builders and successors of moral, intellectual, and aesthetic development." On September 10, 2018, General Secretary Xi Jinping emphasized at the National Education Conference: "We must adhere to the development path of socialist education with Chinese characteristics and cultivate socialist builders and successors of moral, intellectual, artistic, and 
artistic development." For the first time, the school's goal of educating people has been clearly added to the new requirements of "labor" based on the "morality, intelligence, healthy and beautiful". The Secretary-General's latest statement on the educational policy also puts higher demands on the educational goals of colleges and universities. The meaning of "labor" has also become richer with the development of the times. The current "labor" not only includes social production practices in the traditional sense, but for the majority of students, it refers more to the quality of responsibility, this also reflects the sense of responsibility of the colleges and universities in China in accordance with the law of physical and mental development of college students.

\section{CONCLUSION}

a hundred years of planning, education first. The development of a country's political economy and culture depends on education. Therefore, as the main position of talent transfer in China, colleges and universities must thoroughly implement the spirit of the 19th Party Congress, comprehensively implement quality education, and implement the party's education policy. Efforts should be made to cultivate socialist builders and successors of all-round development of morality, intelligence, body, beauty and labor.

\section{REFERENCES}

[1] Mao Zedong. Comrade Mao Zedong on Education Work [M]. Beijing: People's Education Press, 1992.

[2] Deng Xiaoping, Deng Xiaoping, Comrades on Education [M]. Beijing: People's Publishing House, 1995.

[3] He Dongchang. Important Education Documents of the People's Republic of China [M]. Hainan Publishing House, 1998.

[4] Jun Ping. Overview of the Party's Educational Policy since the Founding of the People's Republic of China [J]. Teaching and Research, 1992 (2).

[5] Yang Tianping. A Review of the Educational Policy [J]. Education Guide. 2002(9)

[6] Xiao Zongliu. Education Policy, Education Policy and Education Regulations [J]. People's Education, 1997 (11)

[7] Xiang Xianming. Retrospection and Reflection on the Reform of the 70 -year Education Outlook in New China[J].Journal of Nanjing Normal University(Social Science Edition)2019(2).

[8] Li Fuhua. On the Party's Educational Policy and Its Main Paths for Implementation in Colleges and Universities [J]. China Higher Education Research, 2019 (3)

[9] Liu Jiena. The Evolution of Educational Policy and the Development of China's Socialist Construction [D]. Tianjin Normal University, 2010.6. 